Doi: 10.47650/pjphsr.v1i2.262

ISSN (Online): 2777-1296

OJS: http://journal.unpacti.ac.id/index.php/pjphsr

\title{
RISK FACTORS FOR STUNTING IN CHILDREN AGED 0-23 MONTHS IN THE WORKING AREA OF THE LIUKANG TUPABIRING HEALTH CENTER
}

\section{Faktor Risiko Stunting Pada Anak Umur 0-23 Bulan di Wilayah Kerja Puskesmas Liukang Tupabbiring}

\author{
Muhammad Rezkiyangsyah ${ }^{1 *}$, Andi Maryam², Risma Haris ${ }^{2}$ \\ ${ }^{1}$ Mahasiswa Program Studi Ilmu Kesehatan Masyarakat, Program Pascasarjana Universitas Indonesia Timur, Makassar \\ ${ }^{2}$ Program Pascasarjana Universitas Indonesia Timur, Makassar
}

${ }^{*}$ Alamat Korespondensi: rezkirezki242@gmail.com

\begin{tabular}{l}
\hline Article Info \\
\hline Article History \\
Received: 08 Agustus 2021 \\
Revised : 09 Agustus 2021 \\
Accepted : 12 Agustus 2021
\end{tabular}

Keywords :

Parenting,

child nutritional status, risk of stunting.

\begin{abstract}
ABSTRAK
This study aims to analyze the stunting risk factors in children aged 0-23 months in the Liukang Tupabbiring Health Center Work Area. This type of research is observational with a case-control study approach. The population and sample are all mothers with children under five aged 0-23 months in the working area of the Liukang Tupabbiring Health Center, Pangkep and Islands Regency in 2021 as many as 100 children under five with simple random sampling. Twenty-three months as many as 38 children under five consisting of 38 cases and 38 controls with age matching and data collection used are primary and secondary data. Data processing with SPSS. The results showed that there was a risk between maternal parenting $(p=0.004<0.05$ and an OR value of 104) and the nutritional status of children ( $p=0.012<0.05$ and an OR value of 145) with the risk of stunting in children aged 0- 23 months. The conclusion is that parenting and nutritional status are risk factors for stunting. It is hoped that health workers will actively promote nutritious food for mothers who have children under five to prevent stunting.
\end{abstract}

Penelitian ini bertujuan untuk menganalisis faktor risiko stunting pada anak umur 0-23 bulan di Wilayah Kerja Puskesmas Liukang Tupabbiring. Jenis penelitian ini adalah observasional dengan pendekatan case control study. Populasi dan sampel adalah semua ibu yang mempunyai anak balita umur 0-23 bulan di wilayah kerja Puskesmas Liukang Tupabbiring Kabupaten Pangkep dan Kepulauan tahun 2021 sebanyak 100 anak balita dengan pengambilan sampel secara simple random sampling, maka sampel adalah ibu yang mempunyai anak balita usia 0-23 bulan sebanyak 38 anak balita yang terdiri dari 38 kasus dan 38 kontrol dengan dimaching umur serta pengumpulan data yang digunakan adalah data primer dan data sekunder. Pengolahan data dengan SPSS. Hasil penelitian menunjukkan bahwa ada risiko antara pola asuh ibu $(p=0,004<0,05$ serta nilai OR sebesar 104) dan status gizi anak ( $p=0,012<0,05$ serta nilai OR sebesar 145$)$ dengan risiko stunting pada anak umur 0-23 bulan. Kesimpulan diperoleh bahwa pola asuh dan status gizi merupakan faktor risiko stunting. Diharapkan bagi tenaga kesehatan agar aktif mempromosikan makanan bergizi bagi ibu-ibu yang memiliki anak balita dengan tujuan untuk mencegah stunting. 


\section{PENDAHULUAN}

Stunting menjadi isu utama gizi kesehatan masyarakat secara global yang berdampak pada status kesehatan masyarakat terutama di negaranegara berkembang. Secara global, prevalensi pertumbuhan linier masa kanak-kanak mengalami kemunduran, yang umumnya dinyatakan sebagai stunting, telah menurun selama beberapa dekade terakhir, tetapi tetap sangat tinggi (Juari, Kiming and Hadi, 2021). Dalam beberapa kasus, kegagalan pertumbuhan terlihat akibat kemiskinan yang terus-menerus dan meluas, kekurangan gizi kronis, dan paparan lingkungan yang merugikan. Badan Kesehatan Dunia 2012 ssmendukung penurunan 40\% dalam jumlah anak di bawah 5 tahun yang mengalami stunting pada tahun 2025 (WHO), 2014), sebuah komitmen yang diperkuat oleh target 2.2 dari Tujuan Pembangunan Berkelanjutan (Sustainable Development Goals), yang secara eksplisit menguraikan global berjanji untuk mengurangi prevalensi stunting anak. Terlepas dari target jangka panjang ini, kami belum berada di jalur yang tepat untuk mencapainya (OsgoodZimmerman et al., 2018). Berdasarkan Riset Kesehatan Dasar Kementerian Kesehatan Republik Indonesia menunjukkan bahwa prevalensi Balita stunting turun dari $37,2 \%$ pada tahun 2013 menjadi 30.8\% pada tahun 2018 dan prevalensi Baduta stunting juga mengalami penurunan dari $32.8 \%$ pada tahun 2013 menjadi $29,9 \%$ pada tahun 2018 serta prevalensi Balita Gizi Buruk/Gizi Kurang dan Kurus/Sangat Kurus juga cenderung mengalami penurunan pada 2013-2018 (Indonesia, 2018). Kondisi kesehatan dan gizi ibu sebelum dan saat kehamilan serta setelah persalinan mempengaruhi pertumbuhan janin dan risiko terjadinya stunting. Faktor lainnya pada ibu yang mempengaruhi adalah postur tubuh ibu (pendek), jarak kehamilan yang terlalu dekat, ibu yang masih remaja, serta asupan nutrisi yang kurang pada saat kehamilan (Anwar et al., 2019). Hal ini menunjukkan bahwa setengah dari perempuan yang pernah hamil di Indonesia mengalami kehamilan pertama pada usia muda atau remaja. Didalam kandungan, janin akan tumbuh dan berkembang melalui pertambahan berat dan panjang badan, perkembangan otak serta organorgan lainnya seperti jantung, hati, dan ginjal. Janin mempunyai plastisitas yang tinggi, artinya janin akan dengan mudah menyesuaikan diri terhadap perubahan lingkungannya baik yang menguntungkan maupun yang merugikan pada saat itu. Sekali perubahan tersebut terjadi, maka tidak dapat kembali ke keadaan semula (Sugiyanto, Sumarlan and Hadi, 2020). Status stunting muncul dari interaksi berbagai faktor. Faktor risiko stunting melibatkan pola asuh ibu, status hamil kurang energi kronis, faktor sanitasi, penyakit infeksi dan status gizi anak. Kejadian stunting bisa saja terus meningkat apabila faktor-faktor risiko yang telah dijelaskan sebelumnya tidak diperhatikan. Berdasarkan hasil dari studi pendahuluan yang dilakukan kepada 27 anak umur 0-24 bulan di wilayah Kelurahan Mattiro Sompe Kecamatan Liukang Tupabbiring Kabupaten Pangkajene dan Kepulauan terdapat 85 anak usia 0-24 bulan yang mengalami stunting. Penelitian ini bertujun untuk menganalisis faktor risiko stunting pada anak umur 0-23 bulan di wilayah kerja Puskesmas Liukang Tupabbiring Kabupaten Pangkajane Dan Kepulauan.

\section{BAHAN DAN METODE}

Jenis penelitian ini adalah penelitian observasional dengan menggunakan pendekatan case control study dengan tujuan untuk menganalisis faktor risiko stunting pada anak umur 0-23 bulan yang diteliti pada periode waktu yang sama. Penelitian ini dilaksanakan di wilayah kerja Puskesmas Liukang Tupabbiring Kabupaten Pangkep dan Kepulauan pada bulan Juni 2021. Populasi dan sampel dalam penelitian ini adalah semua Ibu yang mempunyai anak balita umur 0-23 bulan di wilayah kerja Puskesmas Liukang Tupabbiring Kabupaten Pangkep dan Kepulauan tahun 2021 sebanyak 100 anak balita serta pengambilan sampel dengan cara teknik simple random sampling serta pengumpulan data melalui wawancara dan observasi menggunakan kuesioner yang ditanyakan langsung kepada responden, dimana respondennya adalah ibu balita. Analisa 
data untuk melihat hubungan variabel independen terhadap variabel dependen dengan menggunakan Chi-Square dengan tingkat kemaknaan $p<\alpha(0,05)$ yang diolah dengan menggunakan bantuan program computer.

\section{HASIL}

Data umum akan menyajikan karakteristik responden penelitian berdasarkan pekerjaan terhadap gambaran risiko stunting.

Tabel 1. Distribusi Karakteristik Responden

\begin{tabular}{|c|c|c|}
\hline Karakteristik Responden & $\mathbf{n}$ & $\%$ \\
\hline \multicolumn{3}{|l|}{ Tingkat Pendidikan } \\
\hline SD & 13 & 32,2 \\
\hline SMP & 17 & 44,7 \\
\hline SMA & 8 & 21,1 \\
\hline \multicolumn{3}{|l|}{ Jenis Pekerjaan } \\
\hline Nelayan & 12 & 31,5 \\
\hline IRT & 26 & 68,5 \\
\hline Total & 38 & 100,0 \\
\hline
\end{tabular}

Berdasarkan tabel 1 di atas, dapat diketahui bahwa besar responden memiliki tingkat pendidikan tamat SMP yaitu sebanyak 17 orang $(44,7 \%)$, tamat SD yaitu sebanyak 13 orang $(32,2 \%)$ sedangkan sebagian kecil responden memiliki tingkat pendidikan tamat SMA yaitu sebanyak 8 orang $(21,1 \%)$, serta sebagian besar responden bekerja sebagai IRT yaitu sebanyak 26 orang $(68,5 \%)$. Sedangkan yang bekerja sebagai nelayan yaitu ssebanyak 12 orang (31,5\%).

Berdasarkan tabel 2, dapat diketahui bahwa proporsi balita yang mengalami stunting lebih banyak pada balita dengan pola asuh ibu yang tidak baik yaitu sebanyak 24 orang $(82,8 \%$ ) dibandingkan dengan balita yang mengalami stunting dengan pola asuh ibu yang baik yaitu sebanyak 3 orang (33,3\%). Hasil analisis Chi-Square risiko antara pola asuh ibu dengan risiko stunting menunjukkan bahwa nilai signifikansi yaitu 0,004 kurang dari $\alpha=$ 0,05 . Maka dapat diambil kesimpulan bahwa secara uji statistik ada risiko antara pola asuh ibu dengan risiko stunting.

Tabel 2 juga menunjukkan bahwa proporsi balita yang mengalami stunting lebih banyak pada balita dengan status gizi tidak normal yaitu sebanyak 23 orang $(82,1 \%)$ dibandingkan dengan balita yang mengalami stunting dengan status gizi normal yaitu sebanyak 4 orang (40,0\%). Hasil analisis Chi-Square risiko antara status gizi anak dengan risiko stunting menunjukkan bahwa nilai signifikansi yaitu 0,012 kurang dari $\alpha=0,05$. Maka dapat diambil kesimpulan bahwa secara uji statistik ada risiko antara status gizi anak dengan risiko stunting.

Tabel 2. Tabulasi Silang Faktor Risiko Stunting

\begin{tabular}{llcccc}
\hline \multirow{2}{*}{ Faktor Risiko } & \multicolumn{2}{c}{ Risiko Stunting } & \multirow{2}{*}{ Total } & \multirow{2}{*}{ p-value (OR) } \\
\cline { 2 - 4 } & & Stunting & Normal & & \\
\hline Pola Asuh ibu & Baik & $3(33,3)$ & $6(66,7)$ & $9(100,0)$ & \multirow{2}{*}{$0,004(104)$} \\
& Tidak baik & $24(82,4)$ & $5(17,2)$ & $29(100,0)$ & \\
\multirow{2}{*}{ Status gizi } & Gizi normal & $4(40,0)$ & $6(60,0)$ & $10(100,0)$ & \multirow{2}{*}{$0,012(145)$} \\
& Gizi tidak normal & $23(82,1)$ & $5(17,9)$ & $28(100,0)$ & \\
\hline
\end{tabular}

Tabel 3. Hasil Analisis Multivariat Faktor Risiko Stunting

\begin{tabular}{lllll}
\hline Variabel & Nilai B & aPOR & $\mathbf{9 5 \% ~ C l}$ & $\boldsymbol{p}$ \\
\hline Status gizi anak & -2.373 & 093 & $018-491$ & 0,005 \\
Konstanta & 3.221 & & & \\
\hline
\end{tabular}


Analisis multivariat dilakukan regresi logistik ganda dengan metode Backward $L R$ (Likehood Ratio) yaitu memasukkan semua variabel independen yang menjadi kandidat ke dalam model regresi logistik kemudian satu per satu variabel independen dikeluarkan dari model berdasarkan kriteria kemaknaan statistik tertentu. Hasil regresi logistik dapat dilihat pada tabel 3.

Berdasarkan tabel 3 dapat dilihat hasil analisis multivariat menggunakan regresi logistik ganda dengan metode Backward LR (Likehood Ratio) didapatkan hasil bahwa faktor yang paling dominan terhadap risiko stunting pada anak adalah status gizi anak dengan $p<0,005$.

\section{PEMBAHASAN}

\section{Pola Asuh Ibu Merupakan Faktor Risiko Stunting}

Berdasarkan hasil penelitian di wilayah kerja Puskesmas Liukang Tupabbiring Kecamatan Liukang Tupabbiring Kabupaten Pangkajene dan Kepulauan proporsi kejadian stunting pada balita dari hasil uji Chi Square lebih banyak pada balita dengan pola asuh ibu yang tidak baik yaitu sebanyak 24 orang $(82,8)$ dengan $p$ value $0,004<$ $\alpha 0,05$ yang berarti ada risiko antara pola asuh ibu dengan risiko stunting dengan nilai OR sebesar 104 sehingga balita dengan pola asuh ibu yang tidak baik memiliki rasio 104 kali lebih besar untuk mengalami stunting dibandingkan dengan pola asuh ibu yang baik.

Perkembangan anak sangat dipengaruhi orang tua sebagai agen sosial. Anak sebagai bagian dari anggota keluarga, dalam pertumbuhannya tidak bisa terlepas dari lingkungan yang merawat dan mengasuhnya. Pola asuh orang tua tentang tumbuh kembang, sangat membantu anak mencapai dan melewati pertumbuhan dan perkembangan sesuai dengan tingkat usianya secara normal. Dengan lebih mengetahui tumbuh kembang anak diharapkan pertumbuhan dan perkembangan anaknya lebih maksimal sehingga dapat menghasilkan derajat kesehatan yang baik (Apriastuti, 2013).
Pola asuh ibu yang tidak baik akan lebih berisiko mengalami stunting pada anak sehingga peran orang tua sangat dibutuhkan didalam pertumbuhan dan perkembangan anaknya untuk mengurangi terjadinya risiko stunting. Penelitian ini sejalan dengan penelitian Widyaningsih dkk, 2018 yang menyebutkan bahwa terdapat hubungan yang signifikan antara keberagaman pangan dan pola asuh ibu dengan kejadian stunting pada balita usia 24-29 tahun (Widyaningsih, Kusnandar and Anantanyu, 2018).

$\mathrm{Hal}$ ini turut didukung oleh penelitian dengan hasil yang sama bahwa proporsi kejadaian stunting pada keluarga miskin di Klaten sebesar $29 \%$. Tiga variabel yang mempengaruhi kejadian tersebut adalah kebiasaan makan orang tua, pengasuhan orang tua dan kebiasaan kebersihan orang tua. Studi lain yang relevan menyebutkan setelah dilakukan uji statistik dengan chi square diperoleh hasil terhadap hubungan yang signifikan antara pola asuh yang diurai menjadi variabel praktek pemberian makanan, rangsangan psikologis dan praktek kebersihan terhadap kejadian stunting pada anak usia 24-59 bulan dengan nilai $p<0,05$ (Lestari, Margawati and Rahfiludin, 2014).

Berdasarkan hasil observasi lapangan saya, maka peneliti melihat bahwa masih banyak orang tua yang kurang memenuhi pemberian makan pada anak yang tidak sesuai dengan konsep makan (isi piringku) yang sehat karena orang tua lebih senang memberikan makanan ringan kepada anaknya sehingga kebutuhan gizi anak tidak terpenuhi dengan baik, pemberian makan pada anak tidak sesuia bahakan hanya memberikan makanan instan dan kurang menkomsumsi ikan, sayur dan buah-buahan.

\section{Status Gizi Anak Merupakan Faktor Risiko Stunting}

Status gizi adalah keadaan tubuh sebagai akibat konsumsi makanan dan penggunaan zatzat gizi. Dibedakan antara status gizi buruk, kurang, baik, dan lebih. Konsumsi makanan berpengaruh terhadap status gizi seseorang. 
Status gizi baik bila tubuh memperoleh cukup zatzat gizi (Fidiantoro and Setiadi, 2013).

Berdasarkan hasil penelitian status gizi anak merupakan risiko stunting pada anak balita di wilayah kerja Puskesmas Liukang Tupabbiring Kecamatan Liukang Tupabbiring Kabupaten Pangkajene dan Kepulauan dengan proporsi balita yang mengalami stunting lebih banyak pada balita dengan status gizi tidak normal yaitu sebanyak 23 orang $(82,1 \%)$ dengan $p$ value $0,012<\alpha 0,05$ yang berarti ada risiko antara status gizi anak dengan risiko stunting dengan nilai OR sebesar 145 sehingga balita dengan status gizi tidak normal memiliki rasio 145 kali lebih besar untuk mengalami stunting dibandingkan dengan status gizi anak normal.

Sejalan dengan penelitian Ni'mah dan Nadhiroh 2015 di hasil studi dari menyebutkan dalam hasil penelitiannya bawah anak yang tidak diberikan ASI eksklusif memiliki potensi 4,6\% mengalami stunting, begitu juga dengan ibu yang berpengetahuan kurang terhadap nutrisi berpotensi 3,8\% memiliki anak yang memiliki stunting. Kedua variabel ini secara tidak langsung menunjukan bahwa status gizi anak berpengaruh terhadap kejadian stunting (Ni'mah and Nadhiroh, 2015). Penelitian lain Sukmawati dkk, 2020 yang juga relevan yaitu mengemukakan adanya hubungan antara anak yang terlahir dengan berat badan rendah dengan kejadian stunting dengan nilai $\mathrm{p}=0,02<005$ (Sukmawati, 2020). Mendukung hal tersebut hasil penelitian dari mempertegas dengan hasil yang menunjukan bahwa terdapat hubungan status gizi yaitu asupan energi, protein, lemak dan karbohidrat yang cukup dengan kejadaian stunting pada balita. Berdasarkan hasil observasi lapangan saya, maka peneliti melihat bahwa sebagian besar anak memiliki status gizi kurang yang disebabkan dari mengkonsumsi makanan yang tidak sehat dan tidak bergizi yang menyebabkan stunting pada anak.

\section{KESIMPULAN DAN SARAN}

Penelitian ini diperoleh kesimpulan bahwa Ada risiko yang kuat antara pola asuh ibu dengan risiko stunting dengan nilai $p$ value $0,004<0,05$ serta nilai OR sebesar 104 serta ada risiko yang kuat antara status gizi anak dengan risiko stunting dengan nilai $p$ value $0,012<0,05$ serta nilai $O R$ sebesar 145.

Bagi pihak puskesmas lebih giat mensosialisasikan pola asuh yang baik dan pemeberian makan pada anak pada masyarakat untuk mencegah terjadianya stunting pada balita serta disarankan bidan-bidan yang ada di puskesmas membantu ibu hamil dalam memantau status gizi mereka serta mengarahkan dengan jelas pola makan yang benar, baik dan seimbang.

\section{DAFTAR PUSTAKA}

Anwar, M. et al. (2019) 'The Effect of Health Social Determinant on the Life Quality of Pregnant Mother', Indian Journal of Public Health Research \& Development. Prof.(Dr) RK Sharma, 10(10), pp. 1604-1608.

Apriastuti, D. A. (2013) ‘Analisis tingkat pendidikan dan pola asuh orang tua dengan perkembangan anak usia 48-60 bulan', Jurnal IImiah Kebidanan, 4(1), pp. 1-14.

Fidiantoro, N. and Setiadi, T. (2013) 'Model penentuan status gizi balita di Puskesmas'. Universitas Ahmad Dahlan.

Indonesia, K. K. R. (2018) 'Hasil utama Riskesdas 2018', Jakarta: Badan Penelitian dan Pengembangan Kesehatan, Kementrian Kesehatan Republik Indonesia.

Juari, S., Kiming, N. and Hadi, A. J. (2021) 'The Relationship between thelmplementation of Nutrition Conscious Families (KADARZI) and the Toddler Nutrition Status: A Cross Sectional Study', Medico Legal Update, 21(2), pp. 1157-1161.

Lestari, W., Margawati, A. and Rahfiludin, Z. (2014) 'Faktor risiko stunting pada anak umur 6-24 bulan di kecamatan Penanggalan kota Subulussalam provinsi Aceh', Jurnal Gizi Indonesia (The Indonesian Journal of Nutrition). Department of Nutrition Science, Faculty of Medicine, Universitas Diponegoro, 3(1), pp. 37-45.

Ni'mah, K. and Nadhiroh, S. R. (2015) 'Faktor yang 
berhubungan dengan kejadian stunting pada balita', Media Gizi Indonesia, 10(1), pp. 13-19.

Osgood-Zimmerman, A. et al. (2018) 'Mapping child growth failure in Africa between 2000 and 2015', Nature. Nature Publishing Group, 555(7694), pp. 41-47.

Sugiyanto, S., Sumarlan, S. and Hadi, A. J. (2020) 'Analysis of Balanced Nutrition Program Implementation Against Stunting in Toddlers', Unnes Journal of Public Health, $9(2)$.

Sukmawati, H. (2020) 'Assistance in Child Feeding Influences the Nutritional Intake of Stunting Children: Randomized Control Trial.', Indian
Journal of Forensic Medicine \& Toxicology, 14(3).

Widyaningsih, N. N., Kusnandar, K. and Anantanyu, S. (2018) 'Keragaman pangan, pola asuh makan dan kejadian stunting pada balita usia 24-59 bulan', Jurnal Gizi Indonesia (The Indonesian Journal of Nutrition). Department of Nutrition Science, Faculty of Medicine, Universitas Diponegoro, 7(1), pp. 22-29.

(WHO), W. H. O. (2014) 'Maternal Mortality: World Health Organization'. 